\title{
The Ecological Physiology of Earth's Second Oxygen Revolution
}

\section{Citation}

Sperling, Erik A., Andrew H. Knoll, and Peter R. Girguis. 2015. The Ecological Physiology of Earth's Second Oxygen Revolution. Annual Review of Ecology, Evolution, and Systematics 46, no. 1: 215-235. doi:10.1146/annurev-ecolsys-110512-135808.

\section{Published Version}

doi:10.1146/annurev-ecolsys-110512-135808

\section{Permanent link}

http://nrs.harvard.edu/urn-3:HUL.InstRepos:30367424

\section{Terms of Use}

This article was downloaded from Harvard University's DASH repository, and is made available under the terms and conditions applicable to Open Access Policy Articles, as set forth at http:// nrs.harvard.edu/urn-3:HUL.InstRepos:dash.current.terms-of-use\#OAP

\section{Share Your Story}

The Harvard community has made this article openly available.

Please share how this access benefits you. Submit a story.

Accessibility 


\title{
[ The Ecological Physiology of EARTh's Second OXYGEN REVOLUTION
}

\author{
Erik A. Sperling, ${ }^{1,2}$ Andrew H. Knoll, ${ }^{2,3}$ and Peter R. Girguis ${ }^{3}$ \\ ${ }^{1}$ Integrative Oceanography Division, Scripps Institution of Oceanography, La Jolla, \\ California 92093 \\ ${ }^{2}$ Department of Earth and Planetary Sciences and ${ }^{3}$ Department of Organismic and \\ Evolutionary Biology, Harvard University, Cambridge, Massachusetts 02138; email: \\ sperling@fas.harvard.edu,aknoll@oeb.harvard.edu,pgirguis@oeb.harvard.edu
}

- Abstract Living animals display a variety of morphological, physiological, and biochemical characters that enable them to live in low-oxygen environments. These features and the organisms that have evolved them are distributed in a regular pattern across dioxygen $\left(\mathrm{O}_{2}\right)$ gradients associated with modern oxygen minimum zones. This distribution provides a template for interpreting the stratigraphic covariance between inferred Ediacaran-Cambrian oxygenation and early animal diversification. Although Cambrian oxygen must have reached $10--20 \%$ of modern levels, sufficient to support the animal diversity recorded by fossils, it may not have been much higher than this. Today's levels may have been approached only later in the Paleozoic Era. Nonetheless, Ediacaran-Cambrian oxygenation may have pushed surface environments across the low, but critical, physiological thresholds required for large, active animals, especially carnivores. Continued focus on the quantification of the partial pressure of oxygen $\left(\mathrm{pO}_{2}\right)$ in the Proterozoic will provide the definitive tests of oxygen-based coevolutionary hypotheses.

Keywords animal evolution, environmental change, Ediacaran, Cambrian, paleontology 


\section{INTRODUCTION}

Around the midpoint of the last century, three discoveries collectively altered our understanding of deep evolutionary history. First, Tyler \& Barghoorn (1954; Barghoorn \& Tyler 1965) documented bacterial microfossils in ca. 1,880-million-year-old chert, more than tripling the length of life's known history on Earth. Subsequent research would double the length of that history again and demonstrate that Earth was a biological planet when the oldest-known, little-metamorphosed sedimentary rocks were deposited nearly 3,500 million years ago (Mya; reviewed in Schopf 2006). Second, geochemical research, initially focused on iron $(\mathrm{Fe})$ formation, suggested that early evolution took place beneath an oxygen-free atmosphere (Holland 1962, Cloud 1968). And, critically important, advances in mass spectrometry made it possible to obtain radiometric age constraints from sedimentary successions that preserved records of biological and environmental history; this enabled scientists to establish a timeline of Earth's early development (Davis et al. 2003).

Two powerful narratives emerged from this research. The evolutionary narrative, constructed from fossils and phylogenies, arcs across the whole of Earth's recorded history and connects microbes in early oceans to the rich biodiversity observed today. In the complementary environmental narrative, habitats that were originally Fe rich and oxygen poor diversified through time to eventually include oxygen-rich settings capable of supporting complex multicellular life. Not surprisingly, these two trajectories quickly came to be viewed as intertwined, and this promoted a coevolutionary picture of Earth and life (Cloud 1968).

The coevolutionary theme of deep Earth history thrives today and is bolstered by decades of research in paleontology and geochemistry. In particular, dioxygen $\left(\mathrm{O}_{2}\right)$ is commonly seen as a master environmental variable, key to both the long-term expansion of biological diversity and the short-term perturbations that have episodically culled species. At the broadest level, it is thought that Earth surface environments have been shaped by two main oxygen revolutions, bracketing the beginning and end of the Proterozoic Eon (e.g., Lyons et al. 2014). The first, $\sim 2,400$ Mya, saw the initial appearance of a persistently oxic atmosphere, with the partial pressure of oxygen $\left(\mathrm{pO}_{2}\right)$ increasing by orders of magnitude from the previous essentially anoxic state. Still, at least in the canonical telling, it stabilized 
at no more than a few percent of present atmospheric levels (PAL). A second redox transition is hypothesized for the end of the Proterozoic Eon, with oxygen approaching modern levels. Both oxygen revolutions are thought to have had dramatic effects on apparent diversity and organismal complexity. If we are to sustain coevolutionary hypotheses, however, we must be able to support them in two ways: with stratigraphic research that links evolution and environmental change in time and through insights from ecological physiology that provide a mechanistic link between biological and environmental changes (Knoll 2013).

In the following pages, we explore the Neoproterozoic oxygen revolution. As the full range of redox conditions experienced in Neoproterozoic and Cambrian seas can be found in present-day oceans, physiological traits that influence, if not govern, species distributions across redox gradients in space may help us understand the evolutionary consequences of redox change through time. With this in mind, we review ecological and physiological data on the spatial distribution of organisms in the modern ocean and present an overview of the morphological and biochemical adaptations that enable diverse taxa to thrive over a range of environmental oxygen concentrations. We then shift to geological observations and synthesize available data on the deep history of life and environments. We conclude by bringing the two data sets together to explore the power of ecological physiology to illuminate evolutionary history on a dynamic planet.

\section{THE PHYSIOLOGICAL ECOLOGY OF $\mathrm{O}_{2}$ IN PRESENT-DAY OCEANS}

$\mathrm{O}_{2}$ is one of the more common allotropes of the element oxygen and currently makes up $\sim 20.8 \%$ of Earth's atmosphere by volume. However, $\mathrm{O}_{2}$ is not uniformly distributed throughout the biosphere, particularly in aquatic habitats, because of the relatively modest solubility of oxygen in water. For example, in freshwater at biologically relevant temperatures, dissolved oxygen can reach $\sim 450 \mu \mathrm{mol} / \mathrm{L}$, which is $\sim 20$ times lower per unit volume than the level found in air. (The solubility of oxygen in saltwater is $\sim 25 \%$ lower.) Moreover, biological processes can influence dissolved $\mathrm{O}_{2}$ concentrations and result in habitats with even less or no $\mathrm{O}_{2}$. Thus, although $\mathrm{O}_{2}$ is replete in the atmosphere, its distribution throughout the biosphere, most of which is ocean, varies widely. 


\section{Aerobic Respiration}

Cellular respiration can broadly be defined as the set of exothermic biochemical reactions that harness energy from the oxidation of exogenous substrates to generate adenosine triphosphate (ATP). Aerobic respiration refers to a subset of these reactions in which $\mathrm{O}_{2}$ is the oxidant (or terminal electron acceptor). $\mathrm{O}_{2}$ is a powerful oxidant with a high reduction potential, and when organic matter is used as the reductant, the free energy yields are among the highest that organisms can capture per unit substrate $(\sim 2,880 \mathrm{~kJ} / \mathrm{mol}$ glucose $)$. By comparison, glucose oxidation using Fe oxides as an oxidant only yields up to $441 \mathrm{~kJ} / \mathrm{mol}$, and free energy yields are even less for other biologically relevant oxidants, such as sulfate.

The use of oxygen clearly provides a means of harnessing a greater amount of energy per unit organic matter. However, although $\mathrm{O}_{2}$ 's potency as an electron acceptor is beneficial for energy generation, it can be deleterious for cellular function because reactive oxygen species can damage or kill cells. Mitigating the deleterious effects of reactive oxygen species is equally critical to the evolution of aerobic life, but this subject has been reviewed well elsewhere (Metcalfe \& Alonso-Alvarez 2010) and so is not addressed here. Animals must also contend with $\mathrm{O}_{2}$ 's aforementioned modest solubility, because cells and tissues are

primarily water and cellular enzymatic machinery only uses dissolved $\mathrm{O}_{2}$. Animals also face habitat-specific challenges with respect to the provision of $\mathrm{O}_{2}$ (e.g., mitigating water or ion loss across gas exchange surfaces). These challenges are not unique to modern organisms, and ancient organisms faced with the same challenges probably evolved coping mechanisms similar to those we see today. Although many morphological adaptations to oxygen provision are captured in the fossil record, biochemical attributes are not. Reviewing the biochemical, physiological, and morphological traits that organisms have evolved to acquire and use $\mathrm{O}_{2}$ enables us to evaluate early animals in the context of their reconstructed redox environments.

\section{The Biochemical and Physiological Challenges of Aerobic Respiration}

All animals must acquire enough $\mathrm{O}_{2}$ to maintain their respiratory and biosynthetic needs. The $\mathrm{O}_{2}$ flux into a cell is a function of environmental concentration, intra- and intercellular concentrations, and diffusion distance. In light of $\mathrm{O}_{2}$ 's solubility in water, investigators have long suggested that when oxygen availability is limited by diffusion, cell size will be restricted to $\sim 1 \mathrm{~mm}$ or less to maintain appropriate diffusion distances (Harvey 1911). Most 
single-celled organisms are indeed smaller than $1 \mathrm{~mm}$, consistent with---if not attributable to---the need to maintain sufficient oxygen diffusion into the cell. Although cells larger than $1 \mathrm{~mm}$ do exist, and some of Harvey's assumptions (such as the requirement that $\mathrm{O}_{2}$ penetrate the full volume of the cell) are not appropriate, single cells are generally small because a higher surface-to-volume ratio facilitates the influx and efflux required to maintain cellular function.

With this constraint on $\mathrm{O}_{2}$ diffusion to individual cells, the challenge for multicellular organisms is to create three-dimensional forms while maintaining an $\mathrm{O}_{2}$ supply to all cells.

Two general strategies exist to achieve this goal: maintaining body shapes that minimize the diffusion distance between the extracellular environment and each individual cell and evolving oxygen-transport systems than deliver $\mathrm{O}_{2}$ throughout the body. Diploblastic animals, such as sponges, placozoans, ctenophores, and cnidarians, illustrate the first strategy (Figure 1a). They maintain appropriate diffusion distances by having only two layers of cells separated by a metabolically inert substance (mesoglea in cnidarians and ctenophores, mesohyl in sponges). Thus, every cell in the organism is essentially in diffusional contact with seawater. Members of these taxa, for example, sponges, jellyfish, and massive coral heads in the tropics, can achieve great size (Figure 1b). However, although their size and diversity of shapes are impressive, closer examination reveals that the maximum diffusion distance at any location on the organism is indeed on the order of 1 $\mathrm{mm}$ (Knoll \& Sperling 2014). Triploblastic animals (those with three cell layers) that depend solely on diffusion must also maintain short diffusion distances, but within a threedimensional form. As a result, they exhibit small and thin body plans, as exemplified by nematodes and flatworms.

\section{<COMP: PLEASE INSERT FIGURE 1 HERE>}

Figure 1 Diploblastic and triploblastic animal body plans. (a) Transmission electron microscopy image through the body of the calcareous sponge Sycon coactum. The sponge has only two cell layers, the external pinacoderm (p) and the internal choanoderm (c), which are separated by a largely metabolically inert mesohyl $(\mathrm{m})$. Both cell layers are in direct contact with seawater (sw). Image courtesy of $\mathrm{S}$. Leys and originally published in Knoll \& Sperling (2014). (b) This body plan allows sponges, such as the pictured giant barrel sponge, Xestospongia muta, and other diploblasts, such as cnidarians and 
ctenophores, to achieve very large sizes while keeping the diffusion distance for oxygen to any cell short. Image courtesy of J. Pawlik. (c) Triploblastic animals with three cell layers (for instance, some nematodes and flatworms) can also obtain oxygen through pure diffusion, but it limits their body plans to very small and thin forms. Larger size requires an oxygen-transport system, as in the pictured polychaete Neoamphitrite robusta. This polychaete lives at $\sim 0.02 \mathrm{~mL} / \mathrm{L}$ dioxygen $\left(\mathrm{O}_{2}\right)$ on the Costa Rica margin and exhibits elaborate branchiae for increased oxygen uptake. Image courtesy of G. Rouse.

The second strategy involves increasing oxygen transport to internal tissues (Figure 1c). Maximizing oxygen availability has key ecological advantages, including the ability to support sustained activity as needed (in active predation, for example, discussed in detail below). Enhanced access to oxygen can be achieved by any or all of the following means: (a) storing and concentrating $\mathrm{O}_{2}$ within fluids and tissues, (b) facilitating $\mathrm{O}_{2}$ flux to metabolically active tissues via circulating oxygen-rich fluids, and (c) biochemically facilitating the diffusion of $\mathrm{O}_{2}$ into cells [**AU: Italics used in an introductory, ironic, or special sense have been removed per house style **]. Because $\mathrm{O}_{2}$ is volatile and cannot be concentrated in a vacuole, as dissolved ions are, storing and concentrating $\mathrm{O}_{2}$ requires specialized $\mathrm{O}_{2}$-binding proteins (also called oxygen-binding pigments). The broad distribution of some of these molecules, such as hemoglobins, across the Tree of Life suggests that they may predate the origin of animals (Hardison 1996), although specific circulating intracellular globins with oxygen-transport functions probably evolved independently in multiple lineages (e.g., deuterostomes; Hoffmann et al. 2012). Oxygenbinding proteins can be described generically as having a single or multiple protein subunits, each of which contains a metal-containing active site that binds or releases $\mathrm{O}_{2}$ as a function of dissolved oxygen concentration, $\mathrm{pH}$, carbon dioxide, or regulatory molecules that alter oxygen affinity. Reversibility of binding is a necessary attribute that allows $\mathrm{O}_{2-}$ binding proteins to load up on $\mathrm{O}_{2}$ where it is most available (e.g., in gills) and to release $\mathrm{O}_{2}$ where it is least abundant (e.g., in muscle). The presence of binding proteins can enhance the rate of diffusion by up to five orders of magnitude (Costa \& Sinervo 2004).

Binding proteins enable animals to achieve $\mathrm{O}_{2}$ concentrations in biological fluids and tissues that are equal to or greater than the per volume concentration of $\mathrm{O}_{2}$ in air. The evolution of circulatory systems and high-surface-area gas exchange organs, which has occurred multiple times across a wide array of taxa, further ensures a continuous supply of 
$\mathrm{O}_{2}$ to tissues well beyond the reach of diffusion. The morphological and physiological diversity of these adaptations in modern animals is tremendous, and paleontological and molecular evidence underscores the likelihood that comparable diversity existed in earlier bilaterians. Indeed, simpler systems in which epithelia act as the gas exchange surface and internal organs are bathed in an open, fluid-filled cavity are still observed today among reptiles and amphibians, many of which are quite active. More sophisticated gas exchange surfaces, such as gills and lungs, and closed circulatory systems are found among vertebrates and some invertebrates, including cephalopods. These features sustain even higher metabolic rates by maximizing the efficacy of $\mathrm{O}_{2}$ uptake (and, for that matter, carbon dioxide emission).

The value of physiological and biochemical adaptations that facilitate $\mathrm{O}_{2}$ acquisition and use is apparent when considering organisms with higher metabolic rates: It comes down to a question of sustaining oxygen flux to metabolically active tissues. However, these same mechanisms are highly effective in enabling an organism to acquire sufficient $\mathrm{O}_{2}$ when environmental concentrations are low. As noted above, $\mathrm{O}_{2}$ acquisition is ultimately a matter of surface area and gradients. The variety of morphologies that increase surface area---as well as the variety of oxygen-binding pigments and cardiopulmonary systems---found across the many extinct and modern taxa illustrates the varied means by which organisms can compensate for a paucity of oxygen in their environment.

\section{The Distribution of Animals with Respect to the Modern Ocean Oxygen Landscape}

For almost 50 years it has been known that low oxygen is a major factor controlling the structure of animal communities in oceans (Sanders 1969). A great deal of research has focused on pelagic animals in low-oxygen settings (Childress 1995), but, as it pertains to

metazoans, Earth's second oxygen revolution was essentially a benthic affair, with pelagic animals proliferating only near the end of the Cambrian radiation (Butterfield 1997, Peterson et al. 2005). For this reason, we focus on the benthos.

Of the low-oxygen regions in the world's oceans, oxygen minimum zones (OMZs) are perhaps the most useful analog in space-for-time translation. Redox profiles in the modern ocean are increasingly well studied as a result of the recent recognition that some OMZs are expanding and shoaling (Bograd et al. 2008, Stramma et al. 2008, Gilly et al. 2013), with potentially negative effects for both pelagic and benthic ecosystems, including 
commercially important fisheries. OMZs intersect the seafloor over large areas of continental margins (Helly \& Levin 2004) and thus provide natural oxygen gradients that can be used to study how animal communities respond to different oxygen levels. The major OMZs are geologically long-lasting features (Levin 2003, Jacobs et al. 2004), so the animals that inhabit them are well adapted to low-oxygen conditions (locally, OMZs are dynamic on glacial-interglacial timescales; Moffitt et al. 2015).

The nature of these adaptations is important in considering their relevance to Proterozoic Earth history: Are they evolutionary novelties derived relatively recently or general strategies that would have been available to early animals? Although the adaptations of the OMZ benthos have not been studied in detail, most of them---including thin body plans, enhanced respiratory surface area, and high-affinity respiratory proteins (Levin 2003)---are relatively straightforward modifications adopted independently by many clades. There is no a priori reason such adaptations would not have been available to early animals as well. The one reported exception to this statement is a recently described loriciferan from an anoxic and sulfidic Mediterranean salt basin (Danovaro et al. 2010). If the data have been interpreted correctly, this animal has irrevocably converted its mitochondria into hydrogenosomes. Although fascinating from a biochemical standpoint, this example has few implications for early animal evolution, as this evolutionary trajectory is a one-way street and the loriciferan presumably cannot function aerobically. (Further, it would require dietary sterols sourced by aerobes.)

For animals with normal mitochondria, the $\mathrm{O}_{2}$ concentration at which metazoans can survive is vanishingly low; the lower threshold beyond which no animals can live remains unknown. For example, animals occur in $\mathrm{OMZ}$ sediments at $\mathrm{O}_{2}$ levels as low as standard oceanographic techniques can measure (e.g., $0.02 \mathrm{~mL} / \mathrm{L} \mathrm{O}_{2}$ via Winkler titration; Levin et al. 2002, Palma et al. 2005, Raman et al. 2014) (Figure 1c; see Figure 2 for nomenclature of oxygen measurement). Even these estimates are conservative, as they measure $\mathrm{O}_{2}$ concentrations in water several meters above the benthos (Breur et al. 2009). Determining the actual minimum levels animals can tolerate will require more sensitive measurements (Revsbech et al. 2009). Regardless, in these microxic (suboxic) conditions, animals tend to be rare (i.e., at reduced density), generally unmineralized, and of low diversity. Such 
environments are dominated by nematodes, oligochaetes, and some polychaetes with extremely small and thin bodies (between 50 and $300 \mu \mathrm{m}$; Levin 2003).

At slightly higher $\mathrm{O}_{2}$ concentrations, animal communities begin to change with respect to body size, diversity, and lifestyle (Figure 3). Macrofaunal taxa (those retained on a 300- $\mu \mathrm{m}$ sieve) typically begin to appear in greater numbers above $\sim 0.1 \mathrm{~mL} / \mathrm{L} \mathrm{O}_{2}$ (Levin 2003). The exact oxygen level differs among locations, reflecting the complex interplay of food availability, release from oxygen limitation, and low predation pressures that controls macrofaunal densities and communities. At these slightly higher oxygen levels (0.1--0.2 $\mathrm{mL} / \mathrm{L} \mathrm{O}_{2}$ ), animals generally still have relatively low diversity but often show density maxima, resulting from an abundance of opportunistic taxa (edge effects; Mullins et al. 1985) (Figure 3c). Macrofauna in this oxygen range are generally deposit feeders and detritivores; food webs appear to be relatively short, with an absence of predators (Sperling et al. 2013a). Megafauna (organisms easily visible to the naked eye) also show edge effects, although their oxygen thresholds are higher than those of macrofauna. Overall body size in a transect through an OMZ thus generally increases with rising oxygen levels (Gooday et al. 2009), although this statement may not hold for certain individual taxa because of the interaction between oxygen tolerance and food supply. Food availability, as measured by percent organic carbon, often has an inverse relationship with oxygen as a result of lower overall utilization at lower oxygen levels (Levin 2003). The edges of OMZs $(\sim 0.3--0.5$ $\mathrm{mL} / \mathrm{L} \mathrm{O}_{2}$ ) support dense communities of megafaunal brittle stars, starfish, crabs, sponges, and shrimp and include more robustly biomineralized organisms. An $\mathrm{O}_{2}$ level of $0.5 \mathrm{~mL} / \mathrm{L}$, which corresponds to the historical definition of an $\mathrm{OMZ}$, is also increasingly being identified by statistical analyses as the approximate level at which oxygen effects on factors such as macrofaunal carnivory and species diversity become less pronounced (Levin \& Gage 1998, Sperling et al. 2013a) (Figure 3d).

\section{<COMP: PLEASE INSERT FIGURE 2 AND 3 HERE>}

Figure 2 Describing the low- $\mathrm{O}_{2}$ state. Today, normal surface ocean concentrations range from $\sim 5$ to $10 \mathrm{~mL} / \mathrm{L}$ depending on temperature and salinity. Oxygen measurement styles include $\mathrm{mL} / \mathrm{L}$ (used by benthic ecologists and many oceanographers); $\mu \mathrm{M}$ or $\mu \mathrm{M} / \mathrm{kg}$ (used by chemists and geochemists); gas tension in mmHg or KPa (used by physiologists); percentage of present atmospheric levels (used by geologists/modelers); and the partial pressure of oxygen, expressed in mass of the atmosphere (matm), percent saturation, and 
$\mathrm{mg} / \mathrm{L} \mathrm{O}_{2}$. Recent years have seen an explosion of conflicting definitions for low- $\mathrm{O}_{2}$ states, especially in the ecological and global change literature. Hofmann et al. (2011) summarized the definitions used or suggested for different oxygen states in $\mathbf{2 9}$ different studies, and the scheme they developed is depicted here. Compared with traditional classification schemes (e.g., Tyson \& Pearson 1991), the operational oxic-hypoxia boundary (or oxic-dysoxic boundary) has shifted slightly lower, from $2 \mathrm{~mL} / \mathrm{L}$ in Tyson \& Pearson to $2 \mathrm{mg} / \mathrm{L}(1.43$ $\mathrm{mL} / \mathrm{L}$ ). The definition of hypoxia varies widely, however, from $4.2 \mathrm{~mL} / \mathrm{L}$ to $0.2 \mathrm{~mL} / \mathrm{L}$. A separate category of severe hypoxia at $0.5 \mathrm{~mL} / \mathrm{L} \mathrm{O}_{2}$ has emerged, with no alternate definitions yet published. The definition of suboxic has also shifted lower, from $0.2 \mathrm{~mL} / \mathrm{L}$ in Tyson \& Pearson to a median of $0.11 \mathrm{~mL} / \mathrm{L}(\sim 5 \mu \mathrm{M})$, although, again, multiple definitions, from $0.05 \mathrm{~mL} / \mathrm{L}$ to $0.32 \mathrm{~mL} / \mathrm{L}$, have been proposed. These definitions, although useful for communication, are operational (e.g., Canfield \& Thamdrup 2009). S = salinity in permill; $\mathbf{P}=$ atmospheric pressure.

Figure 3 Distribution and ecology of macrofaunal organisms with respect to oxygen in the modern ocean. Regression tree analysis of $(a)$ total macrofaunal diversity (Shannon-Wiener diversity index, $\mathrm{H}_{\log 2}^{\prime}$ ) and (b) polychaete carnivore species richness. Regression tree analysis identifies the oxygen level that minimizes variance in a given response variable in the two most homogeneous subsets. Average values for the two subsets are shown as solid black lines, standard deviations are shown as colored bars, and the oxygen level minimizing variance is shown next to the dashed split in italics. Most data are from Sperling et al. (2013a), with additional data from Joydas \& Damodaran (2014) and Levin et al. (2002). $\mathrm{H}^{\prime}$ [**AU: See query above regarding $\mathrm{H}^{* *} \mathrm{*HK}$ : No italics]was calculated from original species lists using the software PRIMER, and regression tree analyses were completed with the software JMP. (c) Macrofaunal polychaete density with respect to oxygen, illustrating edge effects in the $\sim 0.1--0.3 \mathrm{~mL} / \mathrm{L} \mathrm{O}_{2}$ range. Although density appears low above $0.5 \mathrm{~mL} / \mathrm{L}$, this is an artifact of the scale necessary to visualize edge effects. The average density for stations with $>0.5 \mathrm{~mL} / \mathrm{L} \mathrm{O}_{2}$ is $1,786 \pm 2,623$ individuals $/ \mathrm{m}^{2}$, approximately seven times higher than the very low densities at stations with $<0.1 \mathrm{~mL} / \mathrm{L} \mathrm{O}_{2}(251 \pm 207$ individuals $/ \mathrm{m}^{2}$ ). (d) Loess regression of total macrofaunal diversity (blue) and polychaete carnivore species richness (orange). Also shown is the lowest $\mathrm{O}_{2}$ level at which macrofaunal animals have been recorded $\left(0.02 \mathrm{~mL} / \mathrm{L} \mathrm{O}_{2}\right.$, Winkler titration) in near-sediment conductivity-temperature-depth casts (solid line) and the $0.5 \mathrm{~mL} / \mathrm{L} \mathrm{O}_{2}$ level at which ecological responses become relatively unaffected by oxygen levels, at least in macrofaunal benthic invertebrates.

Although OMZs are perhaps our best analogs for ancient low- $\mathrm{O}_{2}$ oceans, several differences between the two need to be considered. Most important, perhaps, are differences in causation. Ancient low-oxygen oceans presumably resulted from equilibrium with a lowoxygen atmosphere. By contrast, modern OMZs sit beneath a relatively high-oxygen atmosphere; $\mathrm{O}_{2}$ depletion at depth reflects high rates of aerobic remineralization of organic matter. $\mathrm{O}_{2}$ minima in the modern ocean are thus also inorganic carbon maxima (Paulmier et 
al. 2011), characterized by low $\mathrm{pH}$. This has implications, for instance, for interpreting the observation that taxa in the core of modern OMZs are often lightly calcified or unmineralized (Levin 2003). The relative lack of mineralization could be related to lowered $\mathrm{pH}$ and carbonate saturation state, the bioenergetics of calcification in hypoxic conditions, or the relative lack of predators in low- $\mathrm{O}_{2}$ environments (e.g., Sperling et al. 2013a). These highly correlated variables are difficult to decouple. Other important ecological parameters (including temperature, organic carbon quantity and quality, light, and pressure) also vary with depth. An exciting future research direction will be to better understand the intertwined roles of these factors and redox in governing modern and ancient ecological patterns.

\section{ECOLOGICAL PHYSIOLOGY OF THE SECOND OXYGEN REVOLUTION}

\section{Oxygen Levels Prior to Late Neoproterozoic Oxygenation}

Broad qualitative consensus exists on the long-term history of biospheric oxygen (e.g., Holland 2006, Lyons et al. 2014). In the Archean Eon (3,800--2,500 Mya), oxygen was, at best, confined to low levels in transient oases within productive parts of the photic zone. Persistent oxygenation of the atmosphere and surface ocean began $\sim 2,400$ Mya, perhaps increasing transiently to relatively high levels (Lyons et al. 2014). Through most of the Proterozoic Eon (2,500--541 Mya), however, $\mathrm{pO}_{2}$ remained low; levels began a second increase to more modern values only near the end of the eon. Current debate focuses on how low Proterozoic $\mathrm{pO}_{2}$ may have been and just when oxygen began its climb to current levels.

Recently, new information on Proterozoic oxygen constraints has emerged from the chromium $(\mathrm{Cr})$ isotopic system. Interrogation of Fe-rich sedimentary rocks has revealed an absence of $\mathrm{Cr}$ isotope fractionation in Meso- and early Neoproterozoic authigenic $\mathrm{Cr}$, but it is present in rocks deposited after $\sim 800$ Mya (Frei et al. 2009, Planavsky et al. 2014). As Cr fractionation often occurs in soils through oxidation reactions with manganese $(\mathrm{Mn})$ oxides, Planavsky et al. (2014) interpreted the earlier Proterozoic signal as evidence of a low- $\mathrm{O}_{2}$ world with limited formation of Mn oxides. Results from a kinetic model indicate midProterozoic and early Neoproterozoic oxygen levels from $0.1 \%$ PAL to $<10 \%$ PAL [**AU: OK? AHK: OK**] on the basis of soil water residence time, with the authors favoring the lower end of this range (Planavsky et al. 2014). 
Planavsky et al. (2014) have taken paleoredox research into new and still uncharted waters. Uncertainties in the hydrodynamics of Proterozoic soil systems, as well as the role of reactive oxygen species rather than atmospheric oxygen in the formation of Mn oxides (Hansel \& Learman, 2015), will fuel continuing debate. Moreover, fractionation has been observed in older, even Archean, rocks, which indicates transient and local oxygenation long before the permanent and global change suggested for $\sim 800$ Mya (Frei et al. 2009, Crowe et al. 2013). Conservatively, then, the $\mathrm{Cr}$ isotopic record is taken to indicate that $\mathrm{O}_{2}$ levels were less than 10\% PAL and quite possibly substantially lower prior to the second oxygen revolution. Warm temperatures in earlier Proterozoic oceans may have contributed to subsurface anoxia through a decreased capacity to transport oxygen, increased rates of aerobic respiration, and enhanced water column stratification (e.g., Gaidos \& Knoll 2012, Ulloa et al. 2012). That noted, evolving organisms responded directly to the dissolved oxygen content of ambient seawater, so that low levels of seawater $\mathrm{O}_{2}$ influenced by high temperature would have the same physiological consequences as low levels of seawater $\mathrm{O}_{2}$ mediated exclusively by low atmospheric oxygen content (albeit with different metabolic implications at different temperatures).

\section{Geological Evidence for Earth's Second Oxygen Revolution}

Unlike Earth's first oxygen revolution, for which geochemical evidence such as the disappearance of mass-independent sulfur isotope fractionation and redox-sensitive detrital grains provides strong quantitative constraints on the magnitude of oxygenation (Pavlov \& Kasting 2002, Farquhar \& Wing 2003, Johnson et al. 2014), the Neoproterozoic-Paleozoic oxygen increase has proved challenging to track directly. What is certain from proxy records is that this interval is characterized by extreme reorganization of the principal biogeochemical cycles in which oxygen participates (Figure 4a). For example, the carbon isotope composition of marine carbonates is strongly enriched throughout the second half of the Neoproterozoic Era and is punctuated by large negative excursions, including two that coincide with global glaciation (Halverson et al. 2005, 2010; Maloof et al. 2010; Macdonald et al. 2013). Although these excursions probably indicate transfers of carbon between different oxidized and reduced reservoirs, their exact relationship to atmospheric oxygen remains unclear (e.g., Schrag et al. 2013). Likewise, the sulfur isotopic record of this interval shows large changes in carbonate-associated sulfate (Fike et al. 2006), as well as a 
dramatic increase in the isotopic fractionation between seawater sulfate and sedimentary sulfide (Canfield \& Teske 1996). Again, however, these records indicate important environmental change while remaining ambiguous with respect to direct atmospheric oxygenation; several nonunique solutions are possible (Canfield \& Teske 1996, Sim et al. 2011, Leavitt et al. 2013).

\section{<COMP: PLEASE INSERT FIGURE 4 HERE>}

Figure 4 The geochemical and paleontological record of early animal evolution. Molecular clock estimates (Erwin et al. 2011) suggest that (O) animals evolved $\sim 780$ Mya, (2) the first rangeomorphs and frondose Ediacaran fossils appeared $~ 580$ Mya, (3) Ediacaran organisms such as Kimberella with higher $\mathrm{O}_{2}$ requirements appeared $\sim 560 \mathrm{Mya}$, the first (4) deeply burrowing trace fossils and (5) small shelly bilaterian fossils appeared in the earliest Cambrian, and ( $(\odot)$ larger organisms such as trilobites and anomalocarids appeared in Cambrian Stages 2 and 3. (a) Carbon isotope chemostratigraphic curve (data from Halverson et al. 2010). (b) Uranium content of anoxic shales. Increased content indicates more oxygenated global conditions (data from Partin et al. 2013). (c) Aggregated iron speciation data. Circles represent the average of regional proportions of anoxic samples, and whiskers represent standard errors. Values represent binned averages for the Tonian + Cryogenian, Ediacaran, and Cambrian periods rather than single points in time. The data from each time bin are not statistically different. Tonian Period begins 1,000 Mya. Panel C adapted from Sperling et al. (2015). Abbreviation: Ord, Ordovician.

The most concrete evidence for oxygenation during the Ediacaran-Cambrian interval comes from redox-sensitive trace metals in carbonaceous shales deposited beneath anoxic waters. Elements such as uranium (U), molybdenum (Mo), vanadium (V), and $\mathrm{Cr}$ are soluble in oxygenated water but become insoluble and complex with organic carbon, sulfides, and/or other mineral phases under anoxic conditions (Tribovillard et al. 2006). This property has long been used to distinguish oxic from anoxic settings, with concentrations above crustal values indicating deposition under an anoxic water column. When anoxia is widespread, however, trace metal concentrations in seawater are low as a result of widespread reducing sinks, and sediments deposited under anoxic waters show little enrichment. Thus, redox-sensitive trace metal abundance in anoxic shales can also be used to estimate the global spread of reducing conditions (Emerson \& Huested 1991, Scott et al. 2008, Algeo \& Rowe 2012, Reinhard et al. 2013). For example, if a shale can independently 
be determined to have been deposited under an anoxic water column (for instance, using Febased redox proxies), sediments deposited during times of widespread global anoxia would be expected to have lower trace metal enrichment because of lower dissolved $\mathrm{O}_{2}$ concentrations in seawater, and the opposite would hold for anoxic sediments in a predominantly oxygenated ocean.

To a first order, studies of redox-sensitive trace metals in anoxic shales demonstrate a clear pattern: $\mathrm{Mo}, \mathrm{V}, \mathrm{U}$, and $\mathrm{Cr}$ show only minor enrichment above crustal values throughout the Mesoproterozoic and Neoproterozoic Eras but dramatic enrichment in latest Neoproterozoic and Phanerozoic shales (Scott et al. 2008, Och \& Shields-Zhou 2012, Sahoo et al. 2012, Partin et al. 2013, Reinhard et al. 2013) (Figure 4b). Although the broad trend is clear, the exact timing of this shift is still being investigated. It is possible that transient Neoproterozoic oxygenation events occurred before the permanent establishment of more $\mathrm{O}_{2}$-rich conditions (Sahoo et al. 2012, Frei et al. 2013). The redox-sensitive trace metal approach directly tracks the prevalence of reducing sinks in the ocean, which strongly, but not entirely, reflects atmospheric oxygenation. For example, as Mo is primarily sequestered in euxinic settings (areas in which free sulfide is present), and euxinia is largely driven by organic carbon loading (Johnston et al. 2010), a change from diffuse to localized organic carbon deposition would drive increased euxinia and, therefore, a change in seawater Mo concentration irrespective of atmospheric $\mathrm{O}_{2}$. That said, when multiple elements---which are removed from the water column under different redox conditions (Tribovillard et al. 2006)---all show parallel trends, it strongly indicates that the ocean became less reducing and more oxygenated around the Proterozoic-Phanerozoic boundary.

The physiological consequences of terminal Proterozoic oxygenation depend critically on $p \mathrm{O}_{2}$ levels before and after this event. By definition, the level of $p \mathrm{O}_{2}$ in the Cambrian surface ocean was sufficient to support the animal diversity recorded by fossils---perhaps 10--20\% PAL (Rhoads \& Morse 1971, Levin 2003; see discussion in Sperling et al. 2015). Although the canonical story suggests oxygenation of the ocean-atmosphere system at present-day levels (e.g., 100\% PAL), newer analyses increasingly suggest more muted Ediacaran-Cambrian oxygenation, with complete oxygenation occurring on a longer timescale (see also Kah \& Bartley 2011). Fe-based redox proxies have demonstrated that some parts of the deep ocean were oxygenated by the mid-Ediacaran (Canfield et al. 2007) 
but also that subsurface anoxia did not disappear across the Proterozoic-Cambrian boundary (Canfield et al. 2008, Gill et al. 2011). Indeed, statistical analyses of Fe data indicate no significant difference between Ediacaran and Cambrian data sets (Figure 4c; Sperling et al. 2015), which implies that full oxygenation occurred later. [Biogeochemical modeling suggests that persistent subsurface anoxia requires atmospheric $\mathrm{pO}_{2}<\sim 40 \%$ PAL, providing an upper bound for Cambrian oxygen levels (Canfield \& Teske 1996).] Even among trace metal data, Sperling et al. (2015) demonstrated a continued increase in U abundance in anoxic shales between the early and late Paleozoic Era. Mo isotopes (Dahl et al. 2010), the global sedimentary sulfate reduction rate (Leavitt et al. 2013), a decreasing magnitude of sulfate sulfur isotope excursions (Gill et al. 2007), and some models of atmospheric $\mathrm{O}_{2}$ (Bergman et al. 2004) also suggest that oxygenation of the oceanatmosphere system continued after the Cambrian Period. Full oxygenation of the oceans is, thus, increasingly being pushed further into the Paleozoic, a view that harkens back to earlier hypotheses based on the distribution of black shales (Berry \& Wilde 1978).

Why, then, did oxygen levels change in the late Neoproterozoic Era? On this subject, no consensus exists. Some have hypothesized that the Neoproterozoic breakup of a supercontinent and subsequent continent-continent collision increased erosional fluxes into the oceans; these fluxes would have boosted nutrient availability while facilitating organic carbon burial (Derry et al. 1992, Campbell \& Squire 2010, Cawood \& Hawkesworth 2014). However, although such a trigger could, in principle, drive $\mathrm{pO}_{2}$ levels upward, the long-term persistence of a new redox stage requires an essentially permanent change in the Earth system. As an example, Laakso \& Schrag (2014) hypothesized that under a low- $\mathrm{pO}_{2}$ atmosphere, much of the phosphorus $(\mathrm{P})$ released by continental weathering would be absorbed on Fe oxides precipitated from rivers and estuaries and never make it into the oceans. Any event that pushed $p \mathrm{O}_{2}$ to higher levels---and end-Proterozoic orogenesis is a reasonable candidate---would change the kinetics of Fe oxidation to allow much more $\mathrm{P}$ to enter and fertilize continental shelf seas. The subsequent burial of this reduced carbon would then allow the oxygen produced by photosynthesis to accumulate in the atmosphere. Alternatively, B. Mills et al. (2014) proposed that a long-term shift in the balance between terrestrial silicate weathering and ocean crust alteration mediated the second oxygen 
revolution. Still others (e.g., Butterfield 2009) speculate that the event that reordered the Earth system was, in fact, the emergence of animals themselves.

In summary, Mesoproterozoic and early Neoproterozoic oceans probably had very low oxygen levels, $\sim 1--10 \%$ PAL or perhaps even lower. Toward the end of the Neoproterozoic Era, in the Cryogenian and Ediacaran Periods, the isotopic records of elements that interact with the oxygen cycle, such as carbon and sulfur, show extreme changes, but these changes have been difficult to relate quantitatively to changing oxygen levels. The inventory of redox-sensitive trace elements in anoxic shales expands dramatically around the Proterozoic-Cambrian boundary, which suggests an important oxygenation event at this time. However, some analyses of these trace metal records, as well as other redox proxies, indicate that the increase in oxygen to modern levels was a protracted event, culminating only in later Paleozoic times.

\section{Ecological Physiology of the Earliest Animals}

Molecular divergence estimates and the organic geochemical record agree that animals probably originated during the later Tonian or Cryogenian Periods (Figure 4; Love et al. 2009, Erwin et al. 2011), hundreds of millions of years before the inferred EdiacaranCambrian oxygenation event. An enduring question is whether the first appearance of metazoan or bilaterian body plans was limited by oxygen levels in early Neoproterozoic oceans (Mills \& Canfield 2014). How do the physiological requirements for animal function compare with geochemical inferences about $\mathrm{pO}_{2}$ levels, if we account for animals of varying size, body plans, and functional capabilities differing in their minimum oxygen requirements?

From a body plan standpoint, the earliest animals must have exemplified the first strategy outlined earlier for coping with $\mathrm{O}_{2}$ limitation. Debate exists about the exact phylogenetic relationships at the base of Metazoa (Nosenko et al. 2013), but all basal lineages are diploblastic. With essentially all cells in diffusional contact with seawater (Figure 1a), and if we assume metabolic rates similar to those of diploblasts [**AU: of diploblasts? AHK: yes**] today, the theoretical oxygen requirements of these organisms would be quite low. Specifically, their metabolic demands per cell would not be drastically different from those of the single-celled eukaryotes that inhabited Proterozoic oceans long before animals arose (Runnegar 1982, Sperling et al. 2013b, Knoll \& Sperling 2014). Thus, the earliest animals 
were unlikely to experience $\mathrm{O}_{2}$ limitations. DB Mills et al. (2014) recently provided experimental confirmation of this inference by demonstrating that a temperate shallowwater sponge, with no apparent adaptations for low-oxygen conditions, was able to survive and even grow at oxygen levels as low as $0.5 \%$ PAL. The oxygen levels required to escape other constraints, such as steroid synthesis (Waldbauer et al. 2011), collagen synthesis, or the development of a UV shield (reviewed in Mills \& Canfield 2014), are also exceedingly low. With an ancestral capacity to survive brief periods of anoxia (Mentel et al. 2014), early diploblasts likely had only minimal oxygen requirements.

Bilaterian (triploblastic) animals have different oxygen demands, and so it is possible that early diploblastic animals were not oxygen limited, but emerging bilaterians were. A substantial body of research uses models to estimate the maximum size of bilaterians at different oxygen levels, under the two general strategies of pure diffusion or a blood vascular system (Alexander 1971; Runnegar 1982, 1991; Payne et al. 2010). Although respiratory pigments and a blood vascular system greatly increase oxygen transport, at least some respiratory pigments evolved early in (or before) animal evolution. Thus, these adaptations are related more to the earliest evolution of bilaterians than to the Cambrian radiation (Erwin et al. 2011). The different modes of oxygen transport---from simple diffusion to complex vascular systems---are, therefore, optimal designs for life below and above a given size threshold (Budd \& Jensen 2000). Previous studies all reached the same conclusion: Under low oxygen levels, with either transport system, bilaterians are limited to small sizes.

To investigate whether Neoproterozoic oxygen levels would actually have limited bilaterian evolution, theoretical equations can be inverted to calculate the minimum oxygen requirement for a small bilaterian. Such calculations indicate that bilaterians can live at $\mathrm{O}_{2}$ values $<0.5 \%$ PAL (Sperling et al. 2013b) and perhaps far lower. A turn to the modern ocean shows that theory and observation are aligned: Bilaterian animals are present in many areas with $<0.1 \mathrm{~mL} / \mathrm{L} \mathrm{O}_{2}(\sim 1.5 \%$ of modern surface ocean concentrations) and some with levels as low as $0.02 \mathrm{~mL} / \mathrm{L}(\sim 0.3 \%)$. Planavsky et al. (2014) considered these theoretical values and empirical observations to be biased toward lower values, because they do not consider alternative life history stages or synergistic effects. However, in our view these are likely overestimates of the minimal oxygen requirements of bilaterians, for the following 
reasons: (a) Alternative life history stages, such as larvae, have higher per-gram metabolic rates but lower total oxygen requirements than adults, for the simple reason that they are smaller (Alexander 1971). (b) Theoretical calculations of minimal $\mathrm{O}_{2}$ requirements assume a perfectly tubular animal with no adaptations to increase respiratory surface area, but this assumption does not represent most known animals (see discussion in Sperling et al. 2013b). (c) The theoretical calculations used metabolic requirements that are likely an overestimate (Braeckman et al. 2013). (d) Empirical observations of bilaterians living at the resolvable edge of low $\mathrm{O}_{2}$ concentrations $(0.02 \mathrm{~mL} / \mathrm{L})$ were conducted using near-sediment conductivity-temperature-depth casts, and actual seafloor oxygen concentrations are even lower (Breur et al. 2009). (e) Finally, synergistic stressors such as sulfide were probably not important in Neoproterozoic oceans (see below). Thus, unless Neoproterozoic atmospheric oxygen levels were considerably lower than is generally hypothesized (for instance, at the lower end of the modeling results in Planavsky et al. 2014), animals with poriferan, diploblastic, or even bilaterian body plans were unlikely to be excluded. Any such animals, however, would have been limited to small body sizes, low metabolic rates, and low-energy feeding strategies (Knoll \& Sperling 2014)---and would be unlikely to fossilize (Sperling 2013). In short, from a physiological standpoint, animals are not a monolithic entity, and the question of whether oxygenation was causally important for the origins of animals and/or bilaterians and whether oxygenation affected the course of the Cambrian radiation are fundamentally different.

\section{Sulfide and Hypoxia Tolerance in Neoproterozoic Oceans}

One particular feature of Neoproterozoic oceans may have made small bilaterians even more tolerant of oxygen levels lower than in the modern ocean, or, indeed, in the ocean at many points in Earth history. Today, sulfide is common in sediments within low-oxygen environments and occasionally reaches the sediment-water interface (Middelburg \& Levin 2009). Sulfide inhibits aerobic respiration and oxygen transport at micromolar concentrations and is thus toxic to aerobic organisms (Grieshaber \& Völkel 1998). Sulfide detoxification mechanisms exist, although many of them are $\mathrm{O}_{2}$ dependent (Somero et al. 1989, Völkel \& Grieshaber 1994). The end result is that survival times under hypoxia in the presence of sulfide are reduced by as much as 30\% compared with hypoxia alone (with variation by taxonomic group and sulfide level; Vaquer-Sunyer \& Duarte 2010). Although 
Mo isotopes and abundance in anoxic shales suggest that Neoproterozoic oceans were probably more sulfidic than modern oceans (Dahl et al. 2010, 2011; Reinhard et al. 2013), modeling of the percentage of seafloor bathed by euxinic waters indicates that this was a minor phenomenon globally, affecting only $\sim 1--5 \%$ of the seafloor (Dahl et al. 2011, Reinhard et al. 2013). Aside from these small regions and adjacent areas where sulfidic water might upwell, euxinic water bodies were irrelevant to early metazoans, as animals essentially cannot live in permanently anoxic waters. The pertinent factor for benthic animals in weakly oxygenated habitats, then, is not the global percentage of euxinic waters, but the exposure to sulfide generated within ambient sediment during normal early diagenesis. Analysis of a data set of thousands of Neoproterozoic shale samples likely deposited under oxic conditions has demonstrated that these sediments have significantly lower levels of pyrite $\left(\mathrm{FeS}_{2}\right)$ than Mesoproterozoic (1,600--1,000 Mya), Paleozoic, and modern samples (Sperling et al. 2015). Oxic Neoproterozoic sediments also have an abundance of Fe phases that are highly reactive to sulfide, so any sulfide produced---biotic or abiotic---would have reacted with $\mathrm{Fe}$ to form $\mathrm{FeS}_{2}$ and buffered the sediments from porewater sulfide buildup. The exact driving forces behind such low Neoproterozoic sulfide generation in sediments have yet to be fully elucidated, but the almost inescapable conclusion is that organisms living in oxic Neoproterozoic benthic environments would have been exposed, at most, to very low sulfide levels.

Benthic organisms have higher respiratory surface area, with respect to size or per unit mass, in waters with lower oxygen levels (Burd 1988, Lamont \& Gage 2000, Jeffreys et al. 2012). However, these adaptations to increase $\mathrm{O}_{2}$ flux can increase the risk of exposure to sulfide. Indeed, animals with higher surface-to-volume ratios to facilitate $\mathrm{O}_{2}$ flux (such as small flat animals or larger animals with enlarged respiratory structures; Figure 1c) are generally at greater risk of sulfide toxicity, as sulfide readily diffuses across membranes and into tissues. This is why sulfide levels matter in ecological considerations of Neoproterozoic seafloors: In a Neoproterozoic ocean in which oxic benthic environments were relatively sulfide poor, animals could have adopted high-surface-area respiratory structures and body plans with less pressure from synergistic sulfide stress. Low-oxygen environments may have been even more habitable to animals than the modern ocean is. 


\section{Ecological Physiology of the Ediacara Biota}

Such physiological considerations can also be applied to the Ediacara biota. Ediacaran assemblages in Newfoundland ( 580--560 Mya; Narbonne \& Gehling 2003) are dominated by rangeomorphs. Rangeomorphs are the earliest large, complex organisms in the fossil record and belong to an extinct clade with controversial affinities. Despite this phylogenetic controversy, most workers have interpreted these organisms as little more than thin layers of epithelia enclosing inert mesoglea-type material (Laflamme et al. 2009). Because of their constructional similarity to diploblastic animals, rangeomorphs and other Ediacaran organisms, such as Dickinsonia (if it had a similar construction; Runnegar 1991), would, like modern sponges, have had essentially all their cells in diffusive contact with seawater. By contrast, large triploblastic Ediacaran organisms, such as Kimberella (commonly but not definitively thought to be related to the mollusks; Fedonkin et al. 2007, Vinther 2015), moved across the seafloor, making extensive scratch marks on the sediment surface (Gehling et al. 2014). The combination of Kimberella's size, locomotion, and feeding mode would have required both a blood vascular system and much higher minimum oxygen levels than those of rangeomorphs.

Consideration of physiological strategy is important when evaluating trends in body size through time. For example, Payne et al. (2009) correctly inferred an important increase in global maximum body size based on the appearance of meter-long (but mm-thick)

Dickinsonia in the fossil record. If, however, Dickinsonia had a diploblastic construction, its oxygen requirements would have been low despite its size. Rather, the stratigraphically coeval Kimberella, only $10 \mathrm{~cm}$ long but muscular, motile, and three dimensional, would herald a significant increase in minimum oxygen demand (portending the Cambrian biota to come).

\section{Ecological Physiology of the Cambrian Radiation}

More than four decades ago, Rhoads \& Morse (1971) recognized that the succession of organisms observed along a gradient from low to high oxygen levels on the present day seafloor recapitulates the sequential appearance of different animal groups during the Cambrian radiation. As already discussed, seafloors with the lowest $\mathrm{O}_{2}$ levels in the modern ocean are characterized by very small and thin animals with essentially no likelihood of fossilization. These animals are succeeded by slightly larger macrofauna capable of leaving 
small surficial traces. As oxygen levels continue to rise, larger and more heavily biomineralized megafauna appear. This basic observation (Rhoads \& Morse 1971) has held up to continued oceanographic research in the intervening decades, with new studies providing increased detail on the oxygen levels at which key changes occur, the variation seen throughout the world's oceans, the role of oxygen (and other environmental variables) in structuring the ecology of communities, and the existence of nonlinear threshold effects in organismal- and community-level responses to oxygen change.

Low-oxygen thresholds have been identified for several important biological responses, ranging from diversity and feeding strategy to organic matter processing efficiency; the exact $\mathrm{O}_{2}$ level of the threshold varies by response (Figure 3). Some responses occur at extremely low oxygen concentrations. For example, along the continental margin of the Arabian Sea, macrofaunal animals dominate organic matter processing above $0.16 \mathrm{~mL} / \mathrm{L} \mathrm{O}_{2}$ but are outcompeted by protists below this level (Woulds et al. 2007). Likewise, Sperling et al. (2013a) found a statistically significant difference in the percentage of polychaete carnivores between their lowest oxygen bin $\left(0--0.2 \mathrm{~mL} / \mathrm{L} \mathrm{O}_{2}\right)$ and all higher- $\mathrm{O}_{2}$ bins. However, a different measure of carnivory, the number of carnivorous species present (an estimate of food web complexity), showed statistically significant increases up to $1.0 \mathrm{~mL} / \mathrm{L}$ $\mathrm{O}_{2}$. Total species-level diversity also probably has a slightly higher threshold (Levin \& Gage 1998). Statistically important splits for macrofaunal diversity and polychaete carnivore species richness in regression tree analysis occur at $\leq 0.22 \mathrm{~mL} / \mathrm{L} \mathrm{O}_{2}(\sim 3.4 \%$ of modern surface ocean levels) (Figure 3a,b). All key morphological, functional and ecological thresholds occur at low levels: Above $\sim 0.5 \mathrm{~mL} / \mathrm{L} \mathrm{O}_{2}(\sim 8 \%$ of modern surface ocean levels), oxygen is relatively unimportant in explaining these ecological factors

\section{(Figure 3d).}

The observation from ecological physiology that carnivory is inhibited at low $\mathrm{pO}_{2}$ levels has important implications for our understanding of Cambrian animal diversification. In filter or deposit feeding, animals can search for and ingest food slowly and continuously. By contrast, active predation is typically a muscular, intense, and anaerobic effort. Animals can generate ATP anaerobically, but it is relatively inefficient and produces reducing equivalents. This incurs an oxygen debt that cannot be paid off in a permanently hypoxic environment. Many paleontologists have argued that the Cambrian explosion of new animal 
body plans is a consequence of the first widespread macropredation (Stanley 1973, Peterson et al. 2005, Butterfield 2007, Dzik 2007). The physiological constraint that relates carnivory to $\mathrm{pO}_{2}$ therefore links ecological drivers of body plan evolution with environmental triggers and allows us to formulate an integrative causal hypothesis for the Cambrian radiation. Clearly, an oxygenation event (even a smaller-magnitude event, of the type toward which various data sets increasingly point) could have moved animal communities past critical ecological thresholds and triggered the observed Cambrian biodiversification.

\section{CONCLUSIONS}

Geochemical data increasingly suggest that Earth's second oxygen revolution was more modest, or at least more protracted, than conventionally envisioned. Pre-revolution oxygen levels were almost certainly much lower than today's, but unless early Neoproterozoic $\mathrm{pO}_{2}$ levels fell near the bottom of the range permitted by Planavsky et al. (2014)'s model calculations, it is doubtful that low oxygen markedly affected the origin and earliest evolution of animals. Early metazoans, however, would have been restricted to small and thin body plans and potentially low densities, with low fossilization potential. By the same token, unless Neoproterozoic $\mathrm{pO}_{2}$ levels fell near the top of Planavsky et al.'s range, the end-Proterozoic increase in oxygen very probably facilitated Cambrian animal diversification. Several lines of geochemical evidence indicate oxygenation near the Proterozoic-Cambrian boundary, but $\mathrm{pO}_{2}$ levels may well have remained relatively low in Cambrian oceans, reaching modern levels only later in the Paleozoic Era. This might intuitively seem to mute the impact of oxygen as a causal factor in Cambrian diversification, but modern oceanographic studies indicate that critical oxygen thresholds with respect to animal function, ecology, and, hence, evolution occur at low $\mathrm{pO}_{2}$ levels.

Much still remains to be learned about the geological history of oxygen, especially regarding $\mathrm{pO}_{2}$ levels before the second oxygen revolution. We will also benefit from improved data on the nonlinear responses of animals to changing $\mathrm{O}_{2}$ levels. Moreover, oxygen is just one factor shaping marine communities, and its interactions with other environmental parameters (for example, temperature, organic carbon quantity and quality, and sulfide) need to be considered within a multivariate framework. It is clear, however, that metazoan communities exhibit several nonlinear responses at low oxygen levels; 
indeed, the most dramatic effects are at these low levels. Consequently, it is possible that the relatively modest oxygenation inferred for the Ediacaran Period could have moved the biosphere past critical physiological thresholds for animal evolution, especially with respect to ecological forcing factors such as carnivory. In other words, it was not the absolute magnitude of late Neoproterozoic oxygenation that was important for the Cambrian radiation, but the relative change with respect to thresholds for animal ecology and physiology. This focus on environmental change does not discount a role for developmental genetics in animal diversification; it underscores that evolution operated within constraints imposed by function, ecology, and, ultimately, environment.

\section{DISCLOSURE STATEMENT}

The authors are not aware of any affiliations, memberships, funding, or financial holdings that might be perceived as affecting the objectivity of this review.

\section{ACKNOWLEDGMENTS}

E.A.S.'s research was supported by Agouron and NAI postdoctoral fellowships and NSFEAR 1324095. P.R.G.'s effort was supported by the National Science Foundation (NSF IOS-1257755). A.H.K.'s research was supported by the NASA Astrobiology Institute. We thank L. Levin, C. Frieder, D. Johnston, and K. Peterson for helpful discussion and G. Halverson, C. Partin, L. Levin, T. Joydas, and R. Damodaran (Cochin University of Science and Technology, Cochin, India, and Center for Marine Living Resources and Ecology, Cochin, India) for providing raw data from published studies used to draft Figures $\mathbf{3}$ and $\mathbf{4}$.

\section{LITERATURE CITED}

Alexander RMN. 1971. Size and Shape. London: Edward Arnold

Algeo TJ, Rowe H. 2012. Paleoceanographic applications of trace-metal concentration data. Chem. Geol. 324--325:6--18 
Barghoorn ES, Tyler SA. 1965. Microorganisms from the Gunflint Chert. Science 147:563--75

Bergman NM, Lenton TM, Watson AJ. 2004. COPSE: a new model of biogeochemical cycling over Phanerozoic time. Am. J. Sci. 304:397--437

Berry WBN, Wilde P. 1978. Progressive ventilation of the oceans---an explanation for the distribution of the lower Paleozoic black shales. Am. J. Sci. 278:257--75

Bograd SJ, Castro CG, Di Lorenzo E, Palacios DM, Bailey H, et al. 2008. Oxygen declines and the shoaling of the hypoxic boundary in the California Current. Geophys. Res. Lett. 35:L12607

Braeckman U, Vanaverbeke J, Vincx M, van Oevelen D, Soetaert K. 2013. Meiofauna metabolism in suboxic sediments: currently overestimated. PLOS ONE 8:e59289

Breur ER, Law GTW, Woulds C, Cowie GL, Shimmield GB, et al. 2009. Sedimentary oxygen consumption and microdistribution at sites across the Arabian Sea oxygen minimum zone (Pakistan margin). Deep-Sea Res. II 56:296--304

Budd GE, Jensen S. 2000. A critical reappraisal of the fossil record of the bilaterian phyla. Biol. Rev. 75:253--95

Burd BJ. 1988. Comparative gill characteristics of Munida quadrispina (Decapoda, Galatheidae) from different habitat oxygen conditions. Can. J. Zool. 66:2320--23

Butterfield NJ. 1997. Plankton ecology and the Proterozoic-Phanerozoic transition. Paleobiology 23:247--62

Butterfield NJ. 2007. Macroevolution and macroecology through deep time. Palaeontology $50: 41--55$

Butterfield NJ. 2009. Oxygen, animals and oceanic ventilation: an alternative view. Geobiology $7: 1--7$

Campbell IH, Squire RJ. 2010. The mountains that triggered the Late Neoproterozoic increase in oxygen: the second great oxidation event. Geochim. Cosmochim. Acta 74:4187--206

Canfield DE, Poulton SW, Knoll AH, Narbonne GM, Ross G, et al. 2008. Ferruginous conditions dominated later Neoproterozoic deep-water chemistry. Science 321:949--52

Canfield DE, Poulton SW, Narbonne GM. 2007. Late-Neoproterozoic deep-ocean oxygenation and the rise of animal life. Science 315:92--95

Canfield DE, Teske A. 1996. Late Proterozoic rise in atmospheric oxygen concentration inferred from phylogenetic and sulphur-isotope studies. Nature 382:127--32 
Canfield DE, Thamdrup B. 2009. Towards a consistent classification scheme for geochemical environments, or, why we wish the term 'suboxic' would go away. Geobiology 7:385--92

Cawood PA, Hawkesworth CJ. 2014. Earth's middle age. Geology 42:503--6

Childress JJ. 1995. Are there physiological and biochemical adaptations of metabolism in deepsea animals? Trends Ecol. Evol. 10(1):30--36

Cloud PE. 1968. Atmospheric and hydrospheric evolution on primitive Earth. Science 160:729-36

Costa DP, Sinervo B. 2004. Field physiology: physiological insights from animals in nature. Annu. Rev. Physiol. 66:209--38

Crowe SA, Dossing LN, Beukes NJ, Bau M, Kruger SJ, et al. 2013. Atmospheric oxygenation three billion years ago. Nature 501:535--38

Dahl TW, Canfield DE, Rosing MT, Frei RE, Gordon GW, et al. 2011. Molybdenum evidence for expansive sulfidic water masses in $~ 750$ Ma oceans. Earth Planet. Sci. Lett. 311:264--74

Dahl TW, Hammarlund EU, Anbar AD, Bond DPG, Gill BC, et al. 2010. Devonian rise in atmospheric oxygen correlated to the radiation of terrestrial plants and large predatory fish. PNAS 107:17911--15

Danovaro R, Dell'Anno A, Pusceddu A, Gambi C, Heiner I, Kristensen RM. 2010. The first metazoa living in permanently anoxic conditions. BMC Biol. 8:30

Davis DW, Williams IS, Krogh TE. 2003. Historical development of zircon geochronology. Rev. Mineral. Geochem. 53:145--81

Derry LA, Kaufman AJ, Jacobsen SB. 1992. Sedimentary cycling and environmental change in the Late Proterozoic: evidence from stable and radiogenic isotopes. Geochim. Cosmochim. Acta 56:1317--29

Dzik J. 2007. The Verdun syndrome: simultaneous origin of protective armour and infaunal shelters at the Precambrian-Cambrian transition. Geol. Soc. Lond. Spec. Publ. 286:405--14

Emerson SR, Huested SS. 1991. Ocean anoxia and the concentrations of molybdenum and vanadium in seawater. Mar. Chem. 34:177--96

Erwin DH, Laflamme M, Tweedt SM, Sperling EA, Pisani D, Peterson KJ. 2011. The Cambrian conundrum: early divergence and later ecological success in the early history of animals. Science 334:1091--97 
Farquhar J, Wing BA. 2003. Multiple sulfur isotopes and the evolution of the atmosphere. Earth Planet. Sci. Lett. 213:1--13

Fedonkin MA, Simonetta A, Ivantsov AY. 2007. New data on Kimberella, the Vendian mollusclike organism (White Sea region, Russia): palaeoecological and evolutionary implications. Geol. Soc. Spec. Publ. 286:157--79

Fike DA, Grotzinger JP, Pratt LM, Summons RE. 2006. Oxidation of the Ediacaran ocean. Nature 444:744--47

Frei R, Gaucher C, Poulton SW, Canfield DE. 2009. Fluctuations in Precambrian atmospheric oxygenation recorded by chromium isotopes. Nature 461:250--53

Frei R, Gaucher C, Stolper D, Canfield DE. 2013. Fluctuations in late Neoproterozoic atmospheric oxidation: $\mathrm{Cr}$ isotope chemostratigraphy and iron speciation of the late Ediacaran lower Arroyo del Soldado Group (Uruguay). Gondwana Res. 23:797--811

Gaidos E, Knoll AH. 2012. Our evolving planet: from the dark ages to an evolutionary renaissance. In Frontiers of Astrobiology, ed. C Impie, J Lunine, J Funes, pp. 132--53. Cambridge, UK: Cambridge Univ. Press

Gehling JG, Runnegar BN, Droser ML. 2014. Scratch traces of large Ediacara bilaterian animals.

\section{J. Paleontol. 88:284--98}

Gill BC, Lyons TW, Saltzman MR. 2007. Parallel, high-resolution carbon and sulfur isotope records of the evolving Paleozoic marine sulfur reservoir. Palaeogeogr. Palaeoclimatol. Palaeoecol. 256:156--73

Gill BC, Lyons TW, Young SA, Kump LR, Knoll AH, Saltzman MR. 2011. Geochemical evidence for widespread euxinia in the later Cambrian ocean. Nature 469:80--83

Gilly WF, Beman JM, Litvin SY, Robison BH. 2013. Oceanographic and biological effects of shoaling of the oxygen minimum zone. Annu. Rev. Mar. Sci. 5:393--420

Gooday AJ, Levin LA, Aranda da Silva A, Bett BJ, Cowie GL, et al. 2009. Faunal responses to oxygen gradients on the Pakistan margin: a comparison of foraminiferans, macrofauna and megafauna. Deep-Sea Res. II 56:488--502

Grieshaber MK, Völkel S. 1998. Animal adaptations for tolerance and exploitation of poisonous sulfide. Annu. Rev. Physiol. 60:33--53

Halverson GP, Hoffman PF, Schrag DP, Maloof AC, Rice AHN. 2005. Toward a Neoproterozoic composite carbon-isotope record. Geol. Soc. Am. Bull. 117:1181--207 
Halverson GP, Wade BP, Hurtgen MT, Barovich KM. 2010. Neoproterozoic chemostratigraphy. Precambrian Res. 182:337--50

Hansel CM, Learman DR. 2015. The geomicrobiology of manganese. In Erlich's Geomicrobiology, ed. HL Ehrlich, DK Newman, A Kappler, pp. 347-420. Boca Raton, FL: CRC. 6th ed.

Hardison RC. 1996. A brief history of hemoglobins: plant, animal, protist, and bacteria. PNAS 93:5675--79

Harvey EN. 1911. Studies on the permeability of cells. J. Exp. Zool. 10:507--56

Helly JJ, Levin LA. 2004. Global distribution of naturally occurring marine hypoxia on continental margins. Deep-Sea Res. I 51:1159--68

Hoffmann FG, Opazo JC, Hoogewijs D, Hankeln T, Ebner B, et al. 2012. Evolution of the globin gene family in deuterostomes: lineage-specific patterns of diversification and attrition. Mol. Biol. Evol. 29:1735--45

Hofmann AF, Peltzer ET, Walz PM, Brewer PG. 2011. Hypoxia by degrees: establishing definitions for a changing ocean. Deep-Sea Res. I 58:1212--26

Holland HD. 1962. Model for the evolution of the Earth's atmosphere. In Petrologic Studies: A Volume in Honor of A.F. Buddington, ed. AEJ Engel, HL James, BF Leonard, pp. 447--77. Boulder, CO: Geol. Soc. Am.

Holland HD. 2006. The oxygenation of the atmosphere and oceans. Philos. Trans. R. Soc. B 361:903--15

Jacobs DK, Haney TA, Louie KD. 2004. Genes, diversity, and geologic processes on the Pacific coast. Annu. Rev. Earth Planet. Sci. 32:601--52

Jeffreys RM, Levin LA, Lamont PA, Woulds C, Whitcraft CR, et al. 2012. Living on the edge: single-species dominance at the Pakistan oxygen minimum zone boundary. Mar. Ecol. Progr. Ser. 470:79--99

Johnson JE, Gerpheide A, Lamb MP, Fischer WW. 2014. $\mathrm{O}_{2}$ constraints from Paleoproterozoic detrital pyrite and uraninite. Geol. Soc. Am. Bull. 126:813--30

Johnston DT, Poulton SW, Dehler CM, Porter S, Husson J, et al. 2010. An emerging picture of Neoproterozoic ocean chemistry: insights from the Chuar Group, Grand Canyon, USA. Earth Planet. Sci. Lett. 290:64--73 
Joydas TV, Damodaran R. 2014. Infaunal macrobenthos of the oxygen minimum zone on the Indian western continental shelf. Mar. Ecol. 35:22--35

Kah LC, Bartley JK. 2011. Protracted oxygenation of the Proterozoic biosphere. Int. Geol. Rev. $53: 1424--42$

Knoll AH. 2013. Systems paleobiology. Geol. Soc. Am. Bull. 125:3--13

Knoll AH, Sperling EA. 2014. Oxygen and animal evolution. PNAS 111:3907--708

Laakso TA, Schrag DP. 2014. Regulation of atmospheric oxygen during the Proterozoic. Earth Planet. Sci. Lett. 388:81--91

Laflamme M, Xiao S, Kowalewski M. 2009. Osmotrophy in modular Ediacara organisms. PNAS 106:14438--43

Lamont PA, Gage JD. 2000. Morphological responses of macrobenthic polychaetes to low oxygen on the Oman continental slope, NW Arabian Sea. Deep-Sea Res. II 47:9--24

Leavitt WD, Halevy I, Bradley AS, Johnston DT. 2013. Influence of sulfate reduction rates on the Phanerozoic sulfur isotope record. PNAS 110:11244--49

Levin LA. 2003. Oxygen minimum zone benthos: adaptation and community response to hypoxia. Oceanogr. Mar. Biol. 41:1--45

Levin LA, Gage JD. 1998. Relationships between oxygen, organic matter and the diversity of bathyal macrofauna. Deep-Sea Res. II 45:129--63

Levin LA, Gutierrez D, Rathburn A, Neira C, Sellanes J, et al. 2002. Benthic processes on the Peru margin: a transect across the oxygen minimum zone during the 1997--98 El Niño. Progr. Oceanogr. 53:1--27

Love GD, Grosjean E, Stalvies C, Fike DA, Grotzinger JP, et al. 2009. Fossil steroids record the appearance of Demospongiae during the Cryogenian period. Nature 457:718--21

Lyons TW, Reinhard CT, Planavsky NJ. 2014. The rise of oxygen in Earth's early ocean and atmosphere. Nature 506:307--15

Macdonald FA, Strauss JV, Sperling EA, Halverson GP, Narbonne GM, et al. 2013. The stratigraphic relationship between the Shuram carbon isotope excursion, the oxygenation of Neoproterozoic oceans, and the first appearance of the Ediacara biota and bilaterian trace fossils in northwestern Canada. Chem. Geol. 362:250--72

Maloof AC, Porter SM, Moore JL, Dudas FO, Bowring SA, et al. 2010. The earliest Cambrian record of animals and ocean geochemical change. Geol. Soc. Am. Bull. 122:1731--74 
Mentel M, Roettge M, Leys S, Tielens AGM, Martin WF. 2014. Of early animals, anaerobic mitochondria, and a modern sponge. Bioessays 36:924--32

Metcalfe NB, Alonso-Alvarez C. 2010. Oxidative stress as a life history constraint: the role of reactive oxygen species in shaping phenotypes from conception to death. Funct. Ecol. 24:984--96

Middelburg J, Levin L. 2009. Coastal hypoxia and sediment biogeochemistry. Biogeosci. Discuss. 6:3655--706

Mills B, Lenton TM, Watson AJ. 2014. Proterozoic oxygen rise linked to shifting balance between seafloor and terrestrial weathering. PNAS 111:4168--72

Mills DB, Canfield DE. 2014. Oxygen and animal evolution: Did a rise of atmospheric oxygen trigger the origin of animals? Bioessays 36:1145--55

Mills DB, Ward LM, Jones C, Sweeten B, Forth M, et al. 2014. The oxygen requirements of sponges: modern analogues for the earliest animals. PNAS 111:9073--78

Moffitt SE, Moffitt RA, Sauthoff W, Davis CV, Hewett K, Hill TM. 2015. Paleoceanographic insights on recent Oxygen Minimum Zone expansion: lessons for modern oceanography. PLOS ONE 10:e0115246

Mullins HT, Thompson JB, McDougall K, Vercoutere TL. 1985. Oxygen-minimum zone edge effects: evidence from central California upwelling system. Geology 13:491--94

Narbonne GM, Gehling JG. 2003. Life after snowball: the oldest complex Ediacaran fossils. Geology 31:27--30

Nosenko T, Schreiber F, Adamska M, Adamski M, Eitel M, et al. 2013. Deep metazoan phylogeny: when different genes tell different stories. Mol. Phylogen. Evol. 67:223--33

Och LM, Shields-Zhou GA. 2012. The Neoproterozoic oxygenation event: environmental perturbations and biogeochemical cycling. Earth-Sci. Rev. 110:26--57

Palma M, Quiroga E, Gallardo VA, Arntz W, Gerdes D, et al. 2005. Macrobenthic animal assemblages of the continental margin off Chile $\left(22^{\circ}\right.$ to $\left.42^{\circ} \mathrm{S}\right)$. J. Mar. Biol. Ass. U.K. $85: 233--45$

Partin CA, Bekker A, Planavsky NJ, Scott CT, Gill BC, et al. 2013. Large-scale fluctuations in Precambrian atmospheric and oceanic oxygen levels from the record of $U$ in shales. Earth Planet. Sci. Lett. 369--370:284--93 
Paulmier A, Ruiz-Pino D, Garcon V. 2011. $\mathrm{CO}_{2}$ maximum in the oxygen minimum zone (OMZ). Biogeosciences 8:239--52

Pavlov AA, Kasting JF. 2002. Mass-independent fractionation of sulfur isotopes in Archean sediments: strong evidence for an anoxic Archean atmosphere. Astrobiology 2:27--41

Payne JL, Boyer AG, Brown JH, Finnegan S, Kowalewski M, et al. 2009. Two-phase increase in the maximum size of life over 3.5 billion years reflects biological innovation and environmental opportunity. PNAS 106:24--27

Payne JL, McClain CR, Boyer AG, Brown JH, Finnegan S, et al. 2010. The evolutionary consequences of oxygenic photosynthesis: a body size perspective. Photosynth. Res. 107:37-57

Peterson KJ, McPeek MA, Evans DAD. 2005. Tempo and mode of early animal evolution: inferences from rocks, Hox, and molecular clocks. Paleobiology 31(Suppl. 5):36--55

Planavsky NJ, Reinhard CT, Wang X, Thompson D, McGoldrick P, et al. 2014. Low midProterozoic atmospheric oxygen levels and the delayed rise of animals. Science 346:635--38

Raman AV, Damodaran R, Levin LA, Ganesh T, Rao YKV, et al. 2014. Macrobenthos relative to the oxygen minimum zone on the East Indian margin, Bay of Bengal. Mar. Ecol. 36:679-700

Reinhard CT, Planavsky NJ, Robbins LJ, Partin CA, Gill BC, et al. 2013. Proterozoic ocean redox and biogeochemical stasis. PNAS 110:5357--62

Revsbech NP, Larsen LH, Gundersen J, Dalsgaard T, Ulloa O, Thamdrup B. 2009. Determination of ultra-low oxygen concentrations in oxygen minimum zones by the STOX sensor. Limnol. Oceanogr. Methods 7:371--81

Rhoads DC, Morse JW. 1971. Evolutionary and ecologic significance of oxygen-deficient marine basins. Lethaia 4:413--28

Runnegar B. 1982. The Cambrian explosion: animals or fossils? J. Geol. Assoc. Aust. 29:395-411

Runnegar B. 1991. Precambrian oxygen levels estimated from the biochemistry and physiology of early eukaryotes. Palaeogeogr. Palaeoclimatol. Palaeoecol. 97:97--111

Sahoo SK, Planavsky NJ, Kendall B, Wang X, Shi X, et al. 2012. Ocean oxygenation in the wake of the Marinoan glaciation. Nature 489:546--49 
Sanders H. 1969. Benthic marine diversity and the stability-time hypothesis. Brookhaven Symp. Biol. 22:71--81

Schopf JW. 2006. Fossil evidence of Archaean life. Philos. Trans. R. Soc. B 361:869--85

Schrag DP, Higgins JA, Macdonald FA, Johnston DT. 2013. Authigenic carbonate and the history of the global carbon cycle. Science 339:540--43

Scott C, Lyons TW, Bekker A, Shen Y, Poulton SW, et al. 2008. Tracing the stepwise oxygenation of the Proterozoic ocean. Nature 452:456--59

Sim MS, Bosak T, Ono S. 2011. Large sulfur isotope fractionation does not require disproportionation. Science 333:74--77

Somero GN, Childress JJ, Anderson A. 1989. Transport, metabolism and detoxification of hydrogen sulfide in animals from sulfide-rich marine environments. Crit. Rev. Aquat. Sci. $1: 591--614$

Sperling EA. 2013. Tackling the 99\%: Can we begin to understand the paleoecology of the small and soft-bodied animal majority? Paleontol. Soc. Pap. 19:77--86

Sperling EA, Frieder CA, Raman AV, Girguis PR, Levin LA, Knoll AH. 2013a. Oxygen, ecology, and the Cambrian radiation of animals. PNAS 110:13446--51

Sperling EA, Halverson GP, Knoll AH, Macdonald FA, Johnston DT. 2013b. A basin redox transect at the dawn of animal life. Earth Planet. Sci. Lett. 371--372:143--55

Sperling EA, Wolock CJ, Morgan AS, Gill BC, Kunzmann M, et al. 2015. Statistical analysis of iron geochemical data suggests limited late Proterozoic oxygenation. Nature 523:451--54

Stanley SM. 1973. An ecological theory for the sudden origin of multicellular life in the late Precambrian. PNAS 70:1486--89

Stramma L, Johnson GC, Sprintall J, Mohrholz V. 2008. Expanding oxygen-minimum zones in the tropical oceans. Science 320:655--58

Tribovillard N, Algeo TJ, Lyons T, Riboulleau A. 2006. Trace metals as paleoredox and paleoproductivity proxies: an update. Chem. Geol. 232:12--32

Tyler SA, Barghoorn ES. 1954. Occurrence of structurally preserved plants in pre-Cambrian rocks of the Canadian Shield. Science 119:606--8

Tyson RV, Pearson TH. 1991. Modern and ancient continental-shelf anoxia: an overview. Geol. Soc. Lond. Spec. Publ. 58:1--24. 
Ulloa O, Canfield DE, DeLong EF, Letelier RM, Stewart FJ. 2012. Microbial oceanography of anoxic oxygen minimum zones. PNAS 109:15996--6003

Vaquer-Sunyer R, Duarte CM. 2010. Sulfide exposure accelerates hypoxia-driven mortality. Limnol. Oceanogr. 55:1075--82

Vinther J. 2015. The origins of molluscs. Palaeontology 58:19--34

Völkel S, Grieshaber MK. 1994. Oxygen-dependent sulfide detoxification in the lugworm Arenicola marina. Mar. Biol. 118:137--47

Waldbauer JR, Newman DK, Summons RE. 2011. Microaerobic steroid biosynthesis and the molecular fossil record of Archean life. PNAS 108:13409--14

Woulds C, Cowie GL, Levin LA, Andersson JH, Middelburg JJ, et al. 2007. Oxygen as a control on seafloor biological communities and their roles in sedimentary carbon cycling. Limnol. Oceanogr. 52:1698--709 

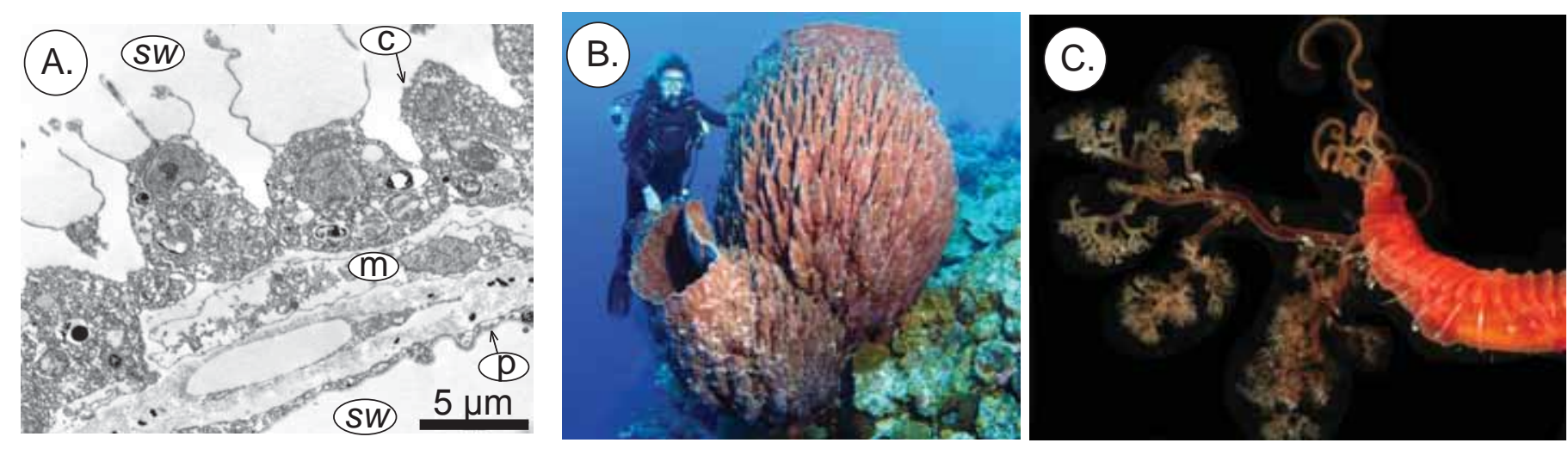


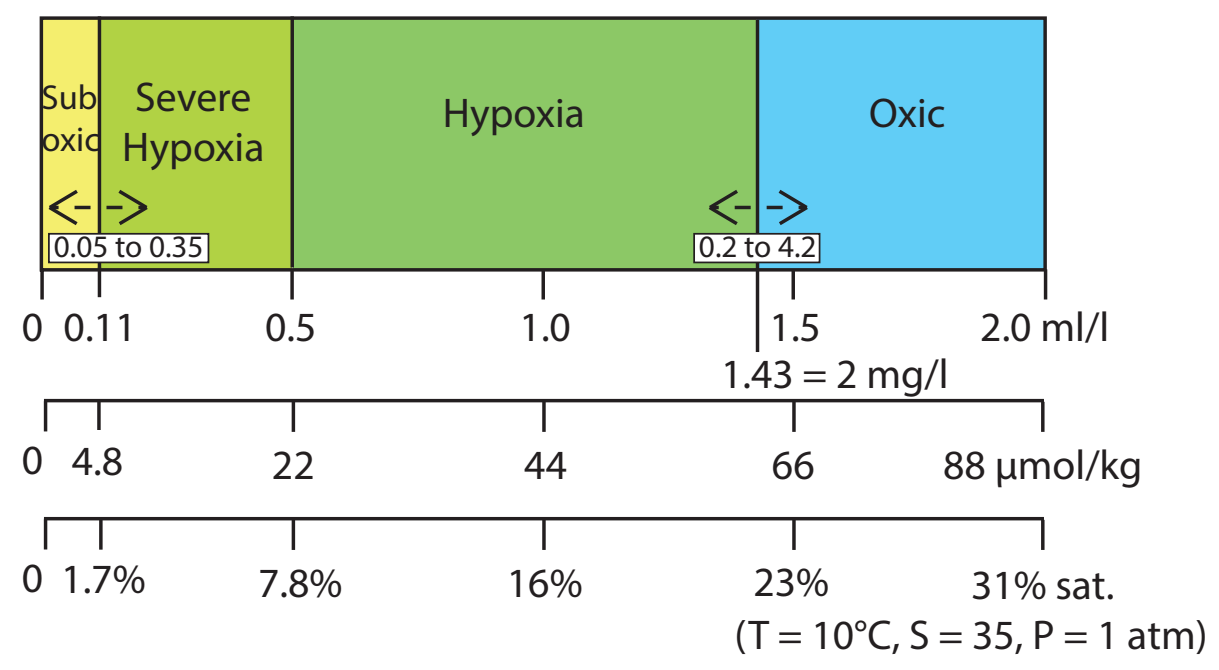


A. Macrofaunal diversity $\left(\mathrm{H}^{\prime}\right)$

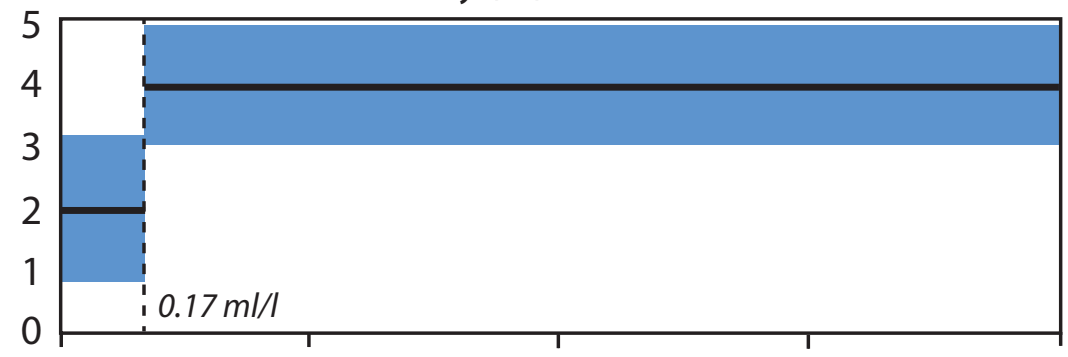

B. Polychaete carnivore species richness
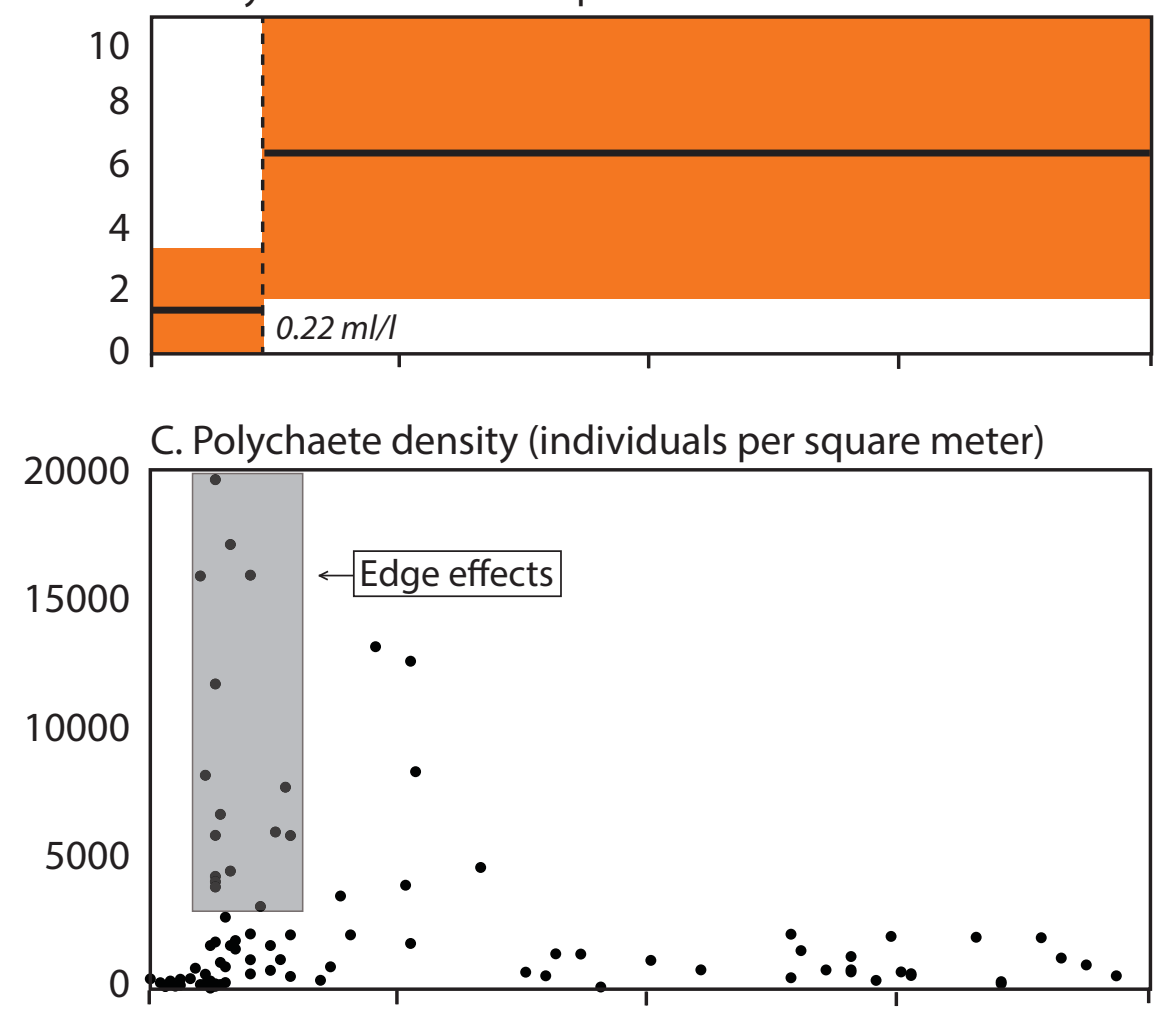

D. Loess regression of total macrofaunal diversity $(A)$ and polychaete carnivore species richness (B)

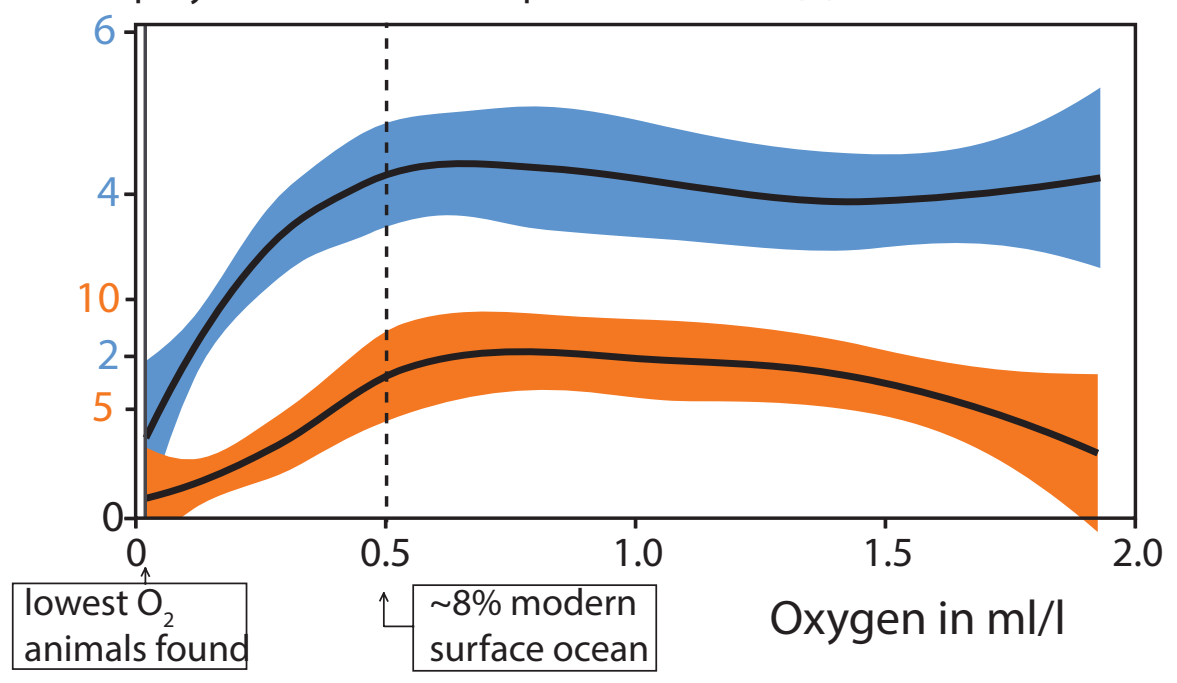




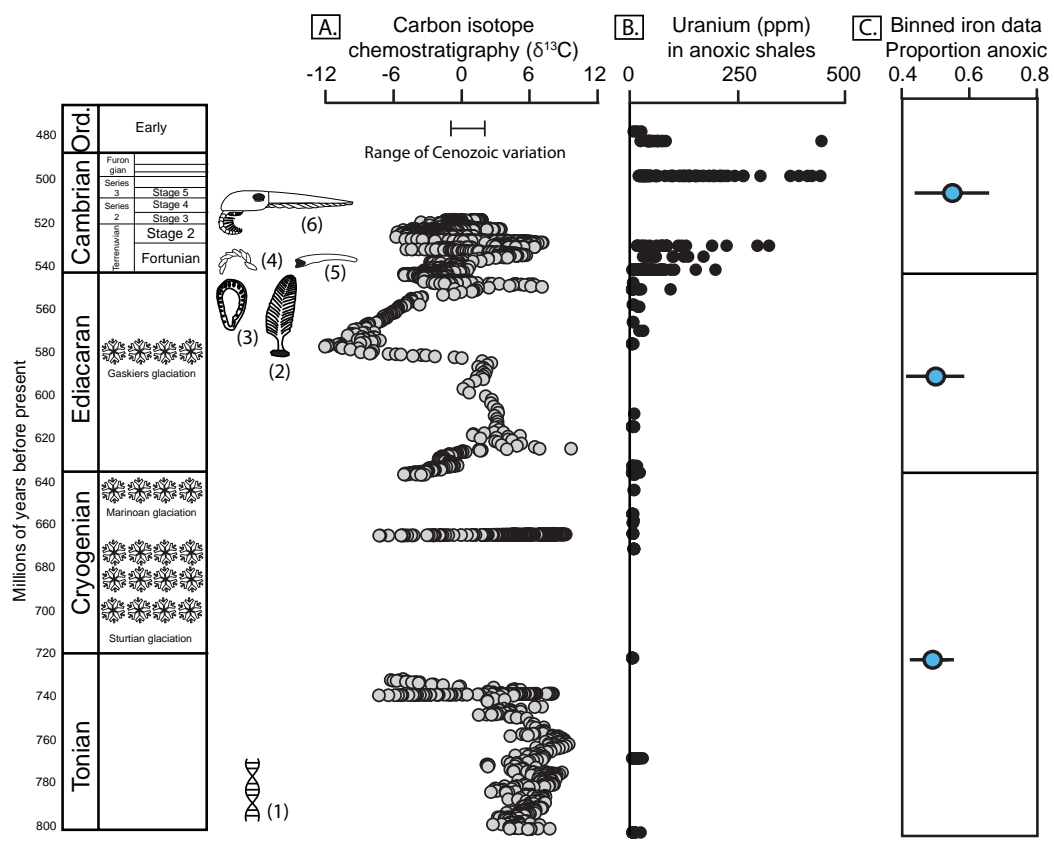

